\title{
Design of Asymmetric Nanofibers-Membranes Based on Polyvinyl Alcohol and Wool-Keratin for Wound Healing Applications
}

\author{
Diego O. Sanchez Ramirez ${ }^{1, *,+} \mathbb{\infty}$, Iriczalli Cruz-Maya ${ }^{2,+} \mathbb{\infty}$, Claudia Vineis $\left.{ }^{1} \mathbb{(}\right)$, Cinzia Tonetti ${ }^{1}$, \\ Alessio Varesano ${ }^{1}$ (D) and Vincenzo Guarino ${ }^{2, *(D)}$ \\ 1 CNR-STIIMA (National Research Council-Institute of Intelligent Industrial Technologies and Systems for \\ Advanced Manufacturing), Corso Giuseppe Pella 16, 13900 Biella, Italy; claudia.vineis@stiima.cnr.it (C.V.); \\ cinzia.tonetti@stiima.cnr.it (C.T.); alessio.varesano@stiima.cnr.it (A.V.) \\ 2 CNR-IPCB (National Research Council-Institute for Polymers, Composites and Biomaterials), Mostra \\ d'Oltremare, Pad. 20, V.le J.F. Kennedy 54, 80125 Napoli, Italy; cdiriczalli@gmail.com \\ * Correspondence: diegoomar.sanchezramirez@stiima.cnr.it (D.O.S.R.); vincenzo.guarino@cnr.it (V.G.) \\ + Equally contributed.
}

check for

updates

Citation: Sanchez Ramirez, D.O.; Cruz-Maya, I.; Vineis, C.; Tonetti, C.; Varesano, A.; Guarino, V. Design of Asymmetric Nanofibers-Membranes Based on Polyvinyl Alcohol and Wool-Keratin for Wound Healing Applications. J. Funct. Biomater. 2021, 12, 76. https://doi.org/10.3390/ jfb12040076

Academic Editor: R. Jayakumar

Received: 11 November 2021 Accepted: 14 December 2021 Published: 20 December 2021

Publisher's Note: MDPI stays neutral with regard to jurisdictional claims in published maps and institutional affiliations.

Copyright: (c) 2021 by the authors. Licensee MDPI, Basel, Switzerland. This article is an open access article distributed under the terms and conditions of the Creative Commons Attribution (CC BY) license (https:/ / creativecommons.org/licenses/by/ $4.0 /)$.

\begin{abstract}
The development of asymmetric membranes-i.e., matching two fibrous layers with selected composition and morphological properties to mimic both the epidermis and dermis-currently represents one of the most promising strategies to support skin regeneration during the wound healing process. Herein, a new asymmetric platform fabricated by a sequential electrospinning process was investigated. The top layer comprises cross-linked polyvinylalcohol (PVA) nanofibers (NFs) - from water solution — to replicate the epidermis's chemical stability and wettability features. Otherwise, the bottom layer is fabricated by integrating PVA with wool-keratin extracted via sulfitolysis. This protein is a biocompatibility polymer with excellent properties for dermis-like structures. Morphological characterization via SEM supported by image analysis showed that the asymmetric membrane exhibited average fiber size-max frequency diameter $450 \mathrm{~nm}$, range $1.40 \mu \mathrm{m}$-and porosity suitable for the healing process. FTIR-spectrums confirmed the presence of keratin in the bottom layer and variations of keratin-secondary structures. Compared with pure PVA-NFs, keratin/PVA-NFs showed a significant improvement in cell adhesion in in vitro tests. In perspective, these asymmetric membranes could be promisingly used to confine active species (i.e., antioxidants, antimicrobials) to the bottom layer to support specific cell activities (i.e., proliferation, differentiation) in wound healing applications.
\end{abstract}

Keywords: wool-keratin; polyvinylalcohol; electrospinning; bilayered fibers; wound healing; asymmetric membranes

\section{Introduction}

Skin is the largest organ in the human body, which acts as a natural barrier to protect other tissues and organs, simultaneously regulating hydration and temperature [1]. The disruption of this tissue by wounds (e.g., surgical procedures, physical or chemical trauma, infection, or specific diseases) gives rise to a complex healing process constituted by hemostasis, inflammation, proliferation, and remodeling phases [2]. However, this reparation process in adults involves fibrosis, resulting in a scar more fragile than the original skin owing to the disorganized extracellular matrix (ECM) [3]. Thus, the development of biomaterials with tunable properties is necessary to support all the different phases of the wound healing process in terms of biocompatibility, hydrophilicity, degradation rate, morphology, mechanical strength, and active agent release [4].

PVA is a synthetic water-soluble polymer, widely used in biomedical and pharmaceutical applications because of its biocompatibility, biodegradability, and non-toxic properties. The presence of hydroxyl groups on PVA increases its hydrophilicity and capacity to create 
good physical/chemical interaction with other molecules [5]. Moreover, PVA has been broadly used in sponges [6], films [7], and hydrogels [8] for wound healing in combination with other natural or synthetic polymers such as alginate [9], chitosan [10], and PLA [11].

In the last years, there has been a substantial increase in studies focused on the fabrication of PVA-NFs as wound dressing devices owing to the high reproducibility of the electrospinning process that can be variously adapted to a wide range of polymers [12]. In particular, the integration of PVA with natural polymers such as proteins was adopted to enhance polypeptide processability and provide specific moieties-i.e., cell-binding sites and biomolecular signatures-able to mimic the innate capability of extracellular matrix to support cell interaction $[13,14]$. Besides, the relevance of proteins as an instructive biomaterial has been widely reported in the literature [15]. In particular, wool and hair keratins include cell-binding motifs, such as leucine-aspartic acid-valine (LDV) binding residues that allow supporting cell adhesion efficiently [16]. Accordingly, other studies have highlighted that keratin presents a strong hydrophilic behavior that improves human mesenchymal stem cells' (hMSCs) proliferation in comparison with other proteins, like zein and gelatin [16]. In this context, the development of nanostructured membranes with asymmetric properties-owing to the addition of keratin to the fibers-certainly suggests new insights to design bioinspired platforms for interface applications.

This work proposes the design of double-layered devices for wound healing applications made of PVA-NFs and keratin/PVA-NFs. Morphological, wettability, and micro and macrostructural properties will be investigated and correlated with keratin/PVA blend ratios and post-treatment conditions (temperature). Lastly, the biological response of hMSC onto the different layers will be assessed by in vitro tests in order to validate their use in the fabrication of promising bi-layered platforms for wound healing applications.

\section{Materials and Methods}

\subsection{Nanofiber Preparation}

As reported in the literature [17], keratin (KS) powder was extracted by sulfitolysis from wool fibers. PVA (average Mw $130 \mathrm{kDa}, \mathrm{CAS}$ no. 9002-89-5) and all other reagents were acquired from Sigma-Aldrich (Milan, Italy), unless otherwise specified.

Solutions were prepared by dissolving separately KS in water at room temperature overnight and PVA in water at about $90^{\circ} \mathrm{C}$ for $2 \mathrm{~h}$, and then cooling them down over night. Two KS solutions were prepared at concentrations of 2.5 and $5.0 \% \mathrm{wt}$., and two PVA solutions were prepared at 9.0 and $15 \%$ wt. The PVA solution at $15 \%$ wt. was blended with KS solutions (2.5 and 5.0\% wt.) at a weight ratio of 1:1 to have KSPVA1 and KSPVA2, respectively. The $9 \% \mathrm{wt}$. PVA solution was electrospun to obtain the pure PVA-NFs top layer.

The production of nanofibrous-membranes was carried out using polymeric solutions in a home-made assembled single jet electrospinning (STIIMA-CNR, Biella, Italy), equipped with an SL50 high-voltage generator (SPELLMAN, Pulborough, UK), a KDS 200 highprecision syringe pump (KD Scientific Inc., Holliston, MA, USA), a stainless-steel needle $(27 \mathrm{Ga})$, and a flat plate collector (Figure 1).

NFs were collected on aluminium using the process conditions reported in Table 1. All the fibrous samples were electrospun for $1 \mathrm{~h}$ at $24^{\circ} \mathrm{C}$ and $60 \% \mathrm{RH}$. Lastly, they were thermally post-treated-at $155^{\circ} \mathrm{C}$ for $3 \mathrm{~min}$ in air [18] or $180^{\circ} \mathrm{C}$ for $2 \mathrm{~h}$ in air [19] in order to prevent the solubilization of proteins in water. 


\section{Sequential electrospinning}

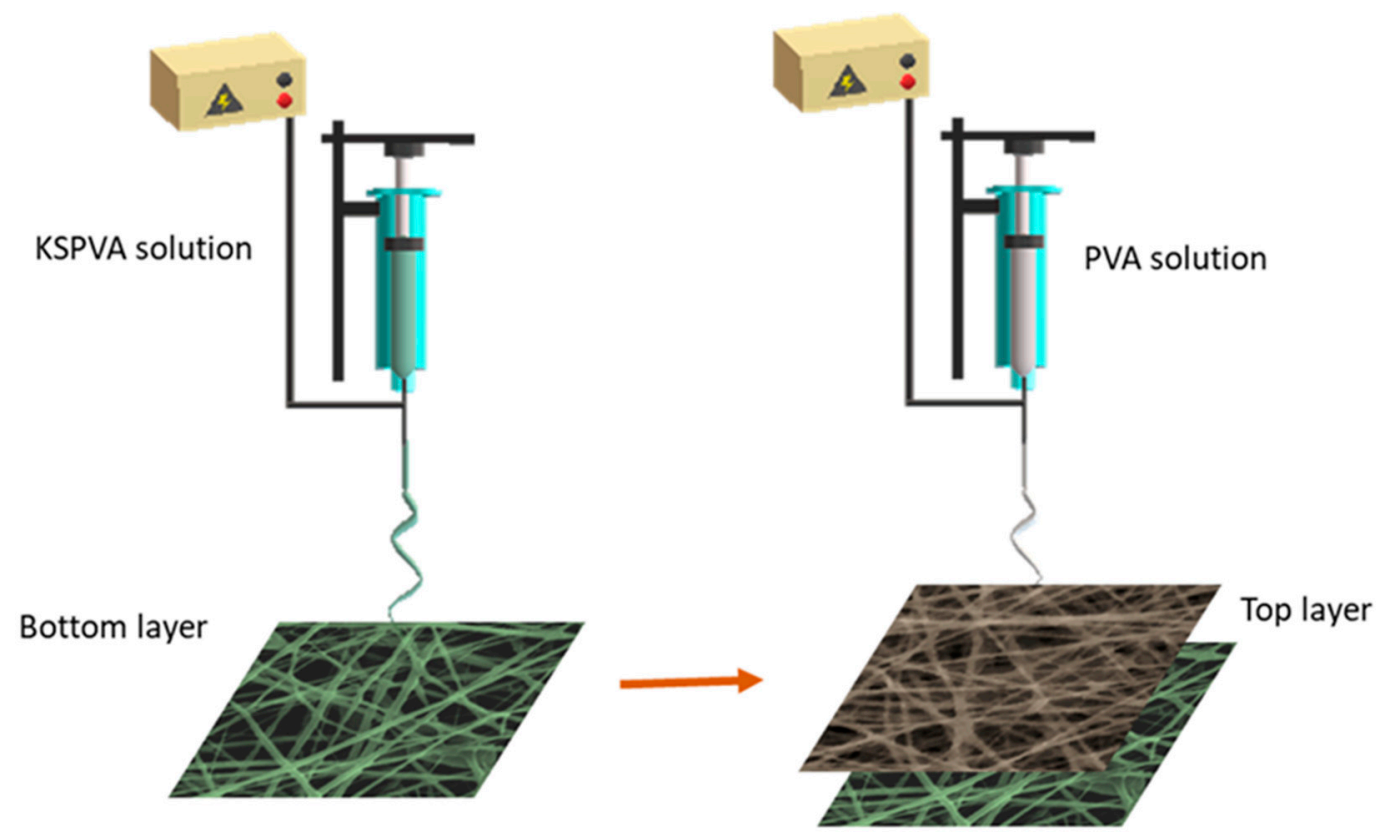

Figure 1. Scheme of sequential electrospinning for PVA and KSPVA nanofibers.

Table 1. Electrospinning conditions.

\begin{tabular}{|c|c|c|c|c|c|c|c|}
\hline Samples & Solvent & $\begin{array}{c}\text { Total Polymer } \\
\text { Concentration } \\
(\% w t)\end{array}$ & $\begin{array}{c}\text { Polymer } \\
\text { Blend }(\% \text { wt) }\end{array}$ & $\begin{array}{c}\text { Flow Rate (mL } \\
\left.\min ^{-1}\right)\end{array}$ & $\begin{array}{l}\text { Tip Collector } \\
\text { Distance }(\mathrm{cm})\end{array}$ & Voltage (kV) & $\begin{array}{c}\text { Needle Inner } \\
\text { Diameter } \\
(\mathrm{mm})\end{array}$ \\
\hline $\begin{array}{c}\text { KSPVA1 } \\
\text { (Bottom-layer) }\end{array}$ & Water & 8.75 & $\begin{array}{c}\text { 17/83 } \\
\text { KS/PVA }\end{array}$ & 0.015 & 30 & 25 & 0.4 \\
\hline $\begin{array}{c}\text { KSPVA2 } \\
\text { (Bottom-layer) }\end{array}$ & Water & 10.00 & $\begin{array}{c}\text { 33/67 } \\
\text { KS/PVA }\end{array}$ & 0.015 & 25 & 25 & 0.4 \\
\hline $\begin{array}{c}\text { PVA } \\
\text { (Up-layer) }\end{array}$ & Water & 9.00 & 100 PVA & 0.008 & 30 & 23 & 0.4 \\
\hline
\end{tabular}

\subsection{Morphological Characterization (SEM)}

A scanning electron microscope (Zeiss EVO-10 GmbH-20 kV and $18 \mathrm{~mm}$, Jena, Germany), was employed to study the morphology of membranes. NFs were coated with a gold-layer $(20 \mathrm{~nm})$ in argon (20 Pa) using a Quorum SC7620 Sputter Coater (20 mA for 120 s, Laughton, UK). The diameter distribution of NFs was measured on SEM images by the software Fiji-ImageJ 1.51.

\subsection{Water Contact Angle (WCA)}

The wettability of NFs was measured by an EasyDrop Standard Contact Angle Measuring system-DSA1 software (KRÜSS GmbH, Hamburg, Germany). The measurements were carried out six times for each sample at $20{ }^{\circ} \mathrm{C}$ and $65 \pm 5 \% \mathrm{RH}$ using $10 \mu \mathrm{L}$ of ultrapure water $\left(1.34 \mu \mathrm{S} \mathrm{cm}^{-1}\right.$ and $\left.72 \mathrm{mN} \mathrm{m}^{-1}\right)$.

\subsection{Water Uptake}

In order to evaluate the water uptake, dry NFs were stored in a conditioned laboratory according to the moisture regain procedure. About $10 \mathrm{mg}$ of thermally post-treated NFs was placed at $105^{\circ} \mathrm{C}$ until a stable weight (dry state). The samples were stored at $20 \pm 2{ }^{\circ} \mathrm{C}$ and $65 \pm 5 \%$ relative humidity for $48 \mathrm{~h}$ and were weighted (wet state). The water uptake in percentage was calculated as the ratio between the weight difference from wet and dry states and the initial weight of NFs in dry state. 


\subsection{Fourier-Transform Infrared Spectroscopy Analysis (FTIR)}

A spectrometer (Thermo Nicolet iN10, Madison, WI, USA) with an iZ10 module and a Smart Endurance accessory was used to record the spectrums in ATR between 4000 and $650 \mathrm{~cm}^{-1}$ (50 scans and $4 \mathrm{~cm}^{-1}$ ).

The secondary structure quantification of samples was carried out by fitting the Amide I peak with Gaussians. For all spectrums, a baseline correction was employed between Amide I and Amide II peaks. The wavenumber of each secondary structure was determined through the second derivate method using the quadratic Savitzky-Golay smoothing (third-order polynomial with five points). The frequency of secondary structures was assigned as follows: intermolecular $\beta$-sheets 1611,1618, 1625, and $1695 \mathrm{~cm}^{-1}$ [20-22]; intramolecular $\beta$-sheets $1674 \mathrm{~cm}^{-1}$ [23]; the bands between 1630 and $1640 \mathrm{~cm}^{-1}$ assigned to inter and/or intramolecular $\beta$-sheets $[23,24]$, and called " $\beta$-sheets II"; $\beta$-turns 1668,1682 , and $1689 \mathrm{~cm}^{-1}$ [21,22]; $\alpha$-helix 1645, 1651, and $1659 \mathrm{~cm}^{-1}$ [25-27]; and random coil 1645, 1651 , and $1659 \mathrm{~cm}^{-1}[25,26]$. Furthermore, the small bands' contributions due to side-chain (1594 and $1604 \mathrm{~cm}^{-1}$ ) and carboxylic groups adsorptions $\left(1714,1725\right.$, and $1731 \mathrm{~cm}^{-1}$ ) were also considered $[25,28,29]$, but the quantification of secondary structures was carried out excluding those areas. Data were analyzed using the function peak analyzer of OriginLabPro 8.0. As reported in the literature, the fitting of Amide I peak was carried out limiting the values of full width at half maximum (FWHM) between 10 and $30 \mathrm{~cm}^{-1}$, allowing any positive value for the height of Gaussians and fixing the band position [25].

\subsection{Cell Culture Tests}

For in vitro assays, human mesenchymal stem cells (hMSCs, SCC034 from SigmaAldrich, Milan, Italy) from 4-6 passages were used. Firstly, hMSCs were cultured to reach the confluence in a $75 \mathrm{~cm}^{2}$ cell culture flask in Eagle's alpha minimum essential medium $(\alpha-$ MEM) supplemented with $10 \%$ fetal bovine serum (Sigma-Aldrich, Milan, Italy), antibiotic solution (streptomycin $100 \mu \mathrm{g} \mathrm{mL}^{-1}$ and penicillin $100 \mathrm{U} \mathrm{mL}^{-1}$, Sigma-Aldrich), and $2 \mathrm{mM}$ of L-glutamine, incubated at $37^{\circ} \mathrm{C}$ in a humidified atmosphere with $5 \% \mathrm{CO}_{2}$ and $95 \%$ air. Before in vitro studies, membranes were cut to be placed in a 96-well cell culture, washed and sterilized in $70 \%$ ethanol for $30 \mathrm{~min}$, and then washed three times with phosphate buffered saline (PBS). All the studies were conducted three times by triplicate. To evaluate the influence on cell adhesion of KSPVA1 and KSPVA2 treated at different temperatures $\left(180\right.$ and $\left.155^{\circ} \mathrm{C}\right), \mathrm{hMSC}$ were seeded onto round samples, at a $2 \times 10^{4}$ for cell adhesion after $24 \mathrm{~h}$. A cell culture plate was used as a control. The morphology of cells was observed at $24 \mathrm{~h}$. Samples were rinsed three times with PBS to remove the non-attached cells, then attached cells were fixed with $4 \%$ paraformaldehyde. Samples were washed with PBS to remove the fixing agent, and then dehydrated in graded series of ethanol (25-100\%) and air dried. The samples were sputter-coating and examined by FESEM under low-vacuum conditions (SEM) (Quanta200 FEI, Eindhoven, The Netherlands).

As for proliferation analyses, counting kit-8 assay (CCK-8; Dojindo Laboratories, Kumamoto, Japan) was performed. hMSCs were seeded at $1 \times 10^{4}$ onto the different groups of KSPVA fibers and PVA. Briefly, the culture media was removed and changed at 1,3 , and 7 days by $100 \mu \mathrm{L}$ of fresh medium with $10 \mu \mathrm{L}$ of CCK-8 reagent per well. After $4 \mathrm{~h}$ of incubation, the supernatant was collected, and absorbance was measured at $450 \mathrm{~nm}$ using a microplate reader. The results are presented as mean \pm standard deviation $(n=3)$. Analysis of variance (ANOVA) Tukey's post hoc was used to detect differences between groups. A value of $p<0.05$ was considered to determine statistically significant differences.

\section{Results}

The morphology and diameter distribution of every single layer are reported in Figure 2. By the SEM images, it is possible to remark that neither thermal treatment $\left(155^{\circ} \mathrm{C}\right.$ for $3 \mathrm{~min}$ and $180^{\circ} \mathrm{C}$ for $2 \mathrm{~h}$ ) nor a greater amount of $\mathrm{KS}$ considerably modified the diameter distribution of NFs (maximum frequency diameter $450 \mathrm{~nm}$, range $1.40 \mu \mathrm{m}$ ). Different trends were recognized for the defects (i.e., beads) that increase with the amount of KS. 
In the literature [30,31], PVA shows a melting point and an onset for thermal degradation above $200^{\circ} \mathrm{C}$. Considering that, any effect of melt or thermal degradation of PVA on NFs can be excluded. Furthermore, it is necessary to highlight that both thermal treatments have different impacts on NFs. A short time at $155^{\circ} \mathrm{C}$ might decrease the amorphous region of PVA and increase the crystalline region of PVA, hindering the diffusion of water molecules into the PVA structure [32]. Using a temperature of $180^{\circ} \mathrm{C}$ for $2 \mathrm{~h}$, not only could the crystalline structure of PVA rise in KSPVA, but also cross-linking reactions between carboxylic groups and amine residues of KS can occur [19].

\section{Top layer}
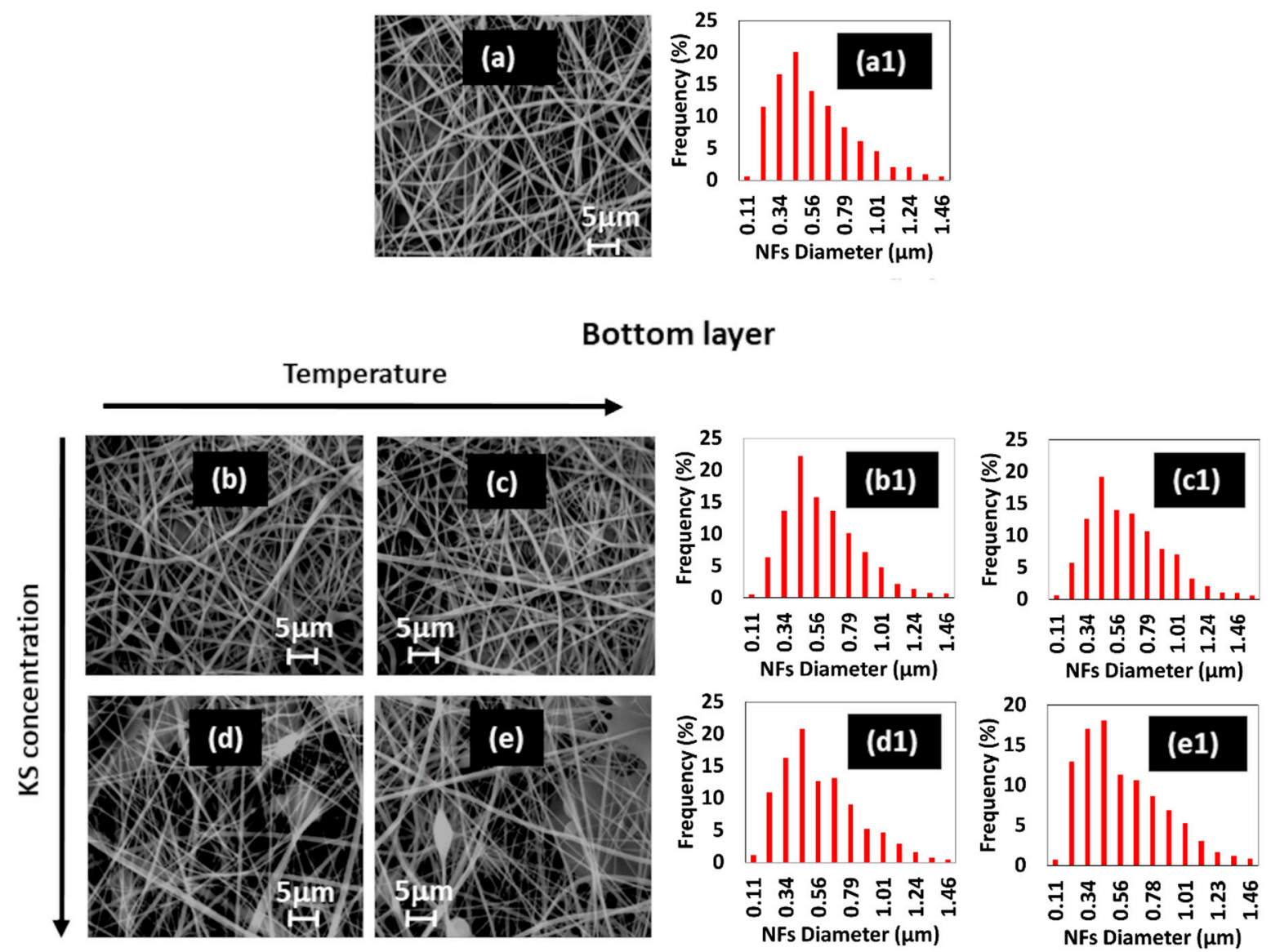

Figure 2. SEM images for samples: (a) PVA as spun, (b) KSPVA $1-155^{\circ} \mathrm{C}$, (c) KSPVA $1-180{ }^{\circ} \mathrm{C}$, (d) $\mathrm{KSPVA} 2-155{ }^{\circ} \mathrm{C}$, and (e) KSPVA2- $180^{\circ} \mathrm{C}$. The corresponding diameter distribution of NFs was labeled with number 1.

The WCAs of all samples are reported in Table 2. Because the water drops were easily absorbed by NFs-membranes, the WCA was estimated at two times: $t_{i}=0 \mathrm{~s}$ and $t_{f}=3.3 \mathrm{~s}$. Furthermore, the WCA variation over time $(\Delta)$ was estimated by the subtraction of WCA at $t_{i}$ and $t_{f}$. From Table 2, it can be observed that a greater temperature considerably reduced the wettability of NFs $\left(\mathrm{WCA}_{\mathrm{ti}}\right)$. At $180^{\circ} \mathrm{C}$, this effect was reinforced by the addition of $\mathrm{KS}$. However, at $155^{\circ} \mathrm{C}$, the effect of KS on wettability was small, in particular for KSPVA2. On the other hand, the interaction between water and NFs over time was enhanced thanks to the presence of KS. However, this interaction was broadly minimized by the post-treatment at the greatest temperature. In fact, the smallest $\Delta$ was obtained for KSPVA 1 at $180{ }^{\circ} \mathrm{C}-2 \mathrm{~h}$, which could regulate the diffusion of aqueous fluids. 
Table 2. WCA for all NFs-membranes at two different times.

\begin{tabular}{ccccc}
\hline Sample & $\begin{array}{c}\text { Thermal } \\
\text { Post-Treatment }\end{array}$ & $\begin{array}{c}\mathbf{W C A}_{\mathbf{t i}}\left({ }^{\circ}\right), \\
\mathbf{0 ~ s}\end{array}$ & $\mathbf{W C A}_{\mathbf{t f}}\left({ }^{\circ}\right), \mathbf{3 . 3} \mathbf{~ s}$ & $\begin{array}{c}\left.\boldsymbol{\Delta} \mathbf{(}^{\circ}\right), \\
\mathbf{W C A}_{\mathbf{t i}}-\mathbf{W C A}_{\mathbf{t f}}\end{array}$ \\
\hline PVA & $155^{\circ} \mathrm{C}-3 \mathrm{~min}$ & $50.2 \pm 2.4$ & $36.6 \pm 1.4$ & 14 \\
KSPVA1 & $155^{\circ} \mathrm{C}-3 \mathrm{~min}$ & $78.3 \pm 4.0$ & $36.7 \pm 10.1$ & 42 \\
KSPVA2 & $155^{\circ} \mathrm{C}-3 \mathrm{~min}$ & $52.6 \pm 3.3$ & $18.3 \pm 6.1$ & 34 \\
PVA & $180^{\circ} \mathrm{C}-2 \mathrm{~h}$ & $67.4 \pm 4.1$ & $51.6 \pm 5.3$ & 16 \\
KSPVA1 & $180^{\circ} \mathrm{C}-2 \mathrm{~h}$ & $131.0 \pm 4.8$ & $123.7 \pm 8.7$ & 7 \\
KSPVA2 & $180^{\circ} \mathrm{C}-2 \mathrm{~h}$ & $127.8 \pm 3.1$ & $107.1 \pm 6.1$ & 21 \\
\hline
\end{tabular}

Water uptakes of dry NFs are listed in Table 3. Pure PVA NFs have the lowest water uptakes, close to $\sim 3 \%$. The water uptakes increase as the KS content increases. The maximum water uptakes were measured on KSPVA2 samples with values of $16.4 \%$ on the sample treated at $155{ }^{\circ} \mathrm{C}$ and $9.7 \%$ on the sample treated at $180^{\circ} \mathrm{C}$.

Table 3. Water uptake percentages of electrospun nanofibers.

\begin{tabular}{ccc}
\hline \multirow{2}{*}{ Sample } & \multicolumn{2}{c}{ Thermal Post-Treatment } \\
\cline { 2 - 3 } & $\mathbf{1 5 5}{ }^{\circ} \mathbf{C}-\mathbf{3} \mathbf{~ m i n}$ & $\mathbf{1 8 0}{ }^{\circ} \mathbf{C}-\mathbf{2} \mathbf{~ h}$ \\
\hline Pure PVA & $3.4 \%$ & $3.3 \%$ \\
\hline KSPVA1 & $4.9 \%$ & $8.5 \%$ \\
\hline KSPVA2 & $16.4 \%$ & $9.7 \%$ \\
\hline
\end{tabular}

FTIR spectrums of all samples are reported in Figure 3 except for KSPVA1, whose spectrums were analogous to those reported by KSPVA2. As KS spectrum is concerned, Amide A peak at $3283 \mathrm{~cm}^{-1}$ is assigned to the stretching vibrations $\mathrm{N}-\mathrm{H}$ bonds. Amide I peak at $1645 \mathrm{~cm}^{-1}$ and amide II peak at $1537 \mathrm{~cm}^{-1}$ are assigned to the stretching vibrations of $\mathrm{C}=\mathrm{O}$ bonds and the in-plane bending modes of $\mathrm{N}-\mathrm{H}$ bonds, with some contributions of $\mathrm{C}-\mathrm{N}$ stretching vibrations. Amide III peak at $1200 \mathrm{~cm}^{-1}$ is assigned to an in-phase combination of $\mathrm{N}-\mathrm{H}$ in-plane bending, $\mathrm{C}-\mathrm{N}$ stretching vibrations, $\mathrm{C}-\mathrm{C}$ stretching, and $\mathrm{C}=\mathrm{O}$ bending vibrations [33], but it also depends on the nature of side-chain groups and hydrogen bonding [34]. The peak at $1024 \mathrm{~cm}^{-1}$ is related to the stretching vibration of the Bunte's salt residues [35].

Regarding PVA, the peak at $3292 \mathrm{~cm}^{-1}$ is attributed to $\mathrm{O}-\mathrm{H}$ stretching vibration, including free hydroxyl groups and inter/intra-molecular hydrogen bonds [32,36]. The side hydroxyl groups in PVA chains interact with each other and form strong hydrogen bonds [32]. The peak at $2906 \mathrm{~cm}^{-1}$ corresponds with the asymmetric and symmetric stretching of $-\mathrm{CH}_{2}$ groups [32,36]. The small peak at $1711 \mathrm{~cm}^{-1}$ is associated with the carbonyl group $(\mathrm{C}=\mathrm{O})$, which is caused by unhydrolyzed acetate groups and free acetate ions in PVA [32]. The two peaks at 1421 and $1323 \mathrm{~cm}^{-1}$ are assigned to the bending of $\mathrm{C}-\mathrm{H}$ [32]. The peak at $1141 \mathrm{~cm}^{-1}$ is mainly ascribed to the crystallinity of PVA, associated with $\mathrm{C}-\mathrm{O}$ in the crystalline region [32]. The peak at $1085 \mathrm{~cm}^{-1}$ corresponds to the $\mathrm{C}-\mathrm{O}$ stretching of PVA [32,36]. The peak at $840 \mathrm{~cm}^{-1}$ is assigned to $C-C$ vibrations [37]. 

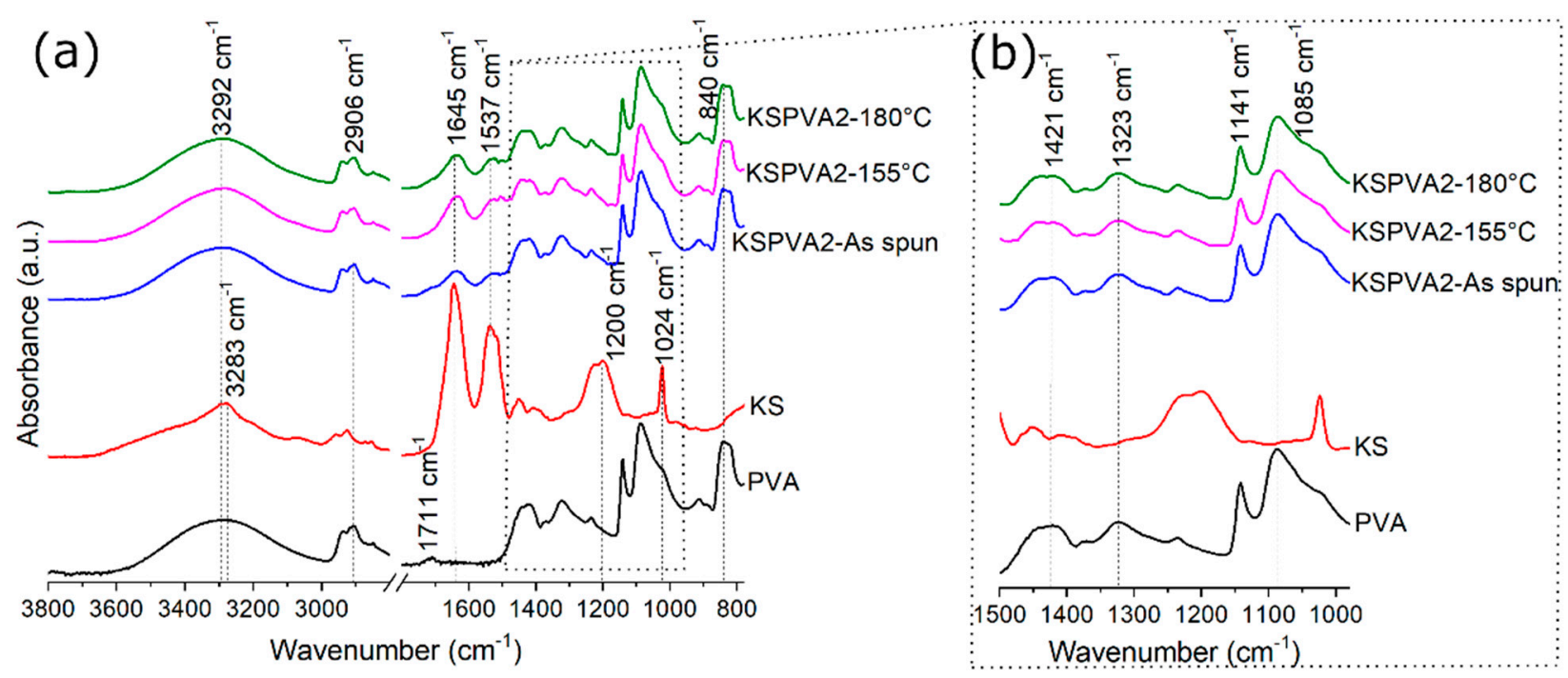

Figure 3. FTIR spectrums before and after post-treatment for NF-membrane made of KS and PVA in water-KS (lyophilized powder) and PVA (powder). (a) Spectrum from 3800 to $2800 \mathrm{~cm}^{-1}$ and from 1800 to $780 \mathrm{~cm}^{-1}$. (b) Spectrum from 1500 to $980 \mathrm{~cm}^{-1}$.

In order to study the effect of KS and thermal treatment on the crystallinity of PVA inside KSPVA-NFs, the peak ratio between the bands at $1141 \mathrm{~cm}^{-1}$ and $1085 \mathrm{~cm}^{-1}$ was calculated, Table 4. In the literature [36], the importance of these peaks to characterize the crystallinity of PVA has already been demonstrated. As observed in Table 4, the electrospinning process has a negative effect on PVA-crystallinity, but at the same time, the use of KS has a positive impact on this property. In terms of thermal treatment, it is observed that a greater temperature increases crystallinity on pure PVA-NFs. The effect of simultaneous variations in KS content and temperature on PVA-crystallinity is at a maximum at $155{ }^{\circ} \mathrm{C}$ with $33 \%$ wt. $\mathrm{KS}$ and minimum at $180{ }^{\circ} \mathrm{C}$ with $17 \%$ wt. KS.

Table 4. Peak ratio $I_{1141} / I_{1085}$.

\begin{tabular}{cccc}
\hline \multirow{2}{*}{ Thermal Post-Treatment } & \multicolumn{3}{c}{ Sample } \\
\cline { 2 - 4 } & PVA & KSPVA1 & KSPVA2 \\
\hline As spun & 0.5813 & 0.7405 & 0.7508 \\
$155^{\circ} \mathrm{C}-3$ min & 0.6779 & 0.7547 & 0.7568 \\
$180^{\circ} \mathrm{C}-2 \mathrm{~h}$ & 0.7611 & 0.7244 & 0.7554 \\
\hline
\end{tabular}

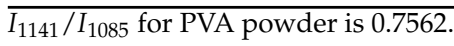

Table 5 reports the content of secondary structures for KS inside NFs-membranes, as solvents and polymers can alter the hydrogen bonds and the conformational properties of polypeptides [38-40].

Table 5. Protein secondary structure content (\%).

\begin{tabular}{|c|c|c|c|c|c|c|}
\hline Sample & $\begin{array}{c}\text { Intermolecular } \\
\beta \text {-Sheet }\end{array}$ & $\begin{array}{c}\text { Intramolecular } \\
\beta-S h e e t\end{array}$ & $\beta$-Sheet II & $\beta$-Turn & Random Coil & $\alpha$-Helix \\
\hline KS (lyophilized powder) & 23.9 & 6.5 & 24.2 & 11.3 & 6.7 & 27.4 \\
\hline KSPVA1, as spun & 23.2 & 5.5 & 13.4 & 17.2 & 2.8 & 37.9 \\
\hline $\mathrm{KSPVA} 1,155^{\circ} \mathrm{C}-3 \mathrm{~min}$ & 24.8 & 5.5 & 10.7 & 16.7 & 1.8 & 40.4 \\
\hline KSPVA1, $180^{\circ} \mathrm{C}-2 \mathrm{~h}$ & 25.8 & 5.6 & 14.1 & 18.5 & 6.0 & 30.0 \\
\hline KSPVA2, as spun & 27.2 & 5.3 & 7.3 & 16.4 & 0.8 & 43.0 \\
\hline $\mathrm{KSPVA} 2,155^{\circ} \mathrm{C}-3 \mathrm{~min}$ & 27.0 & 5.1 & 13.4 & 13.3 & 1.7 & 39.5 \\
\hline $\mathrm{KSPVA} 2,180^{\circ} \mathrm{C}-2 \mathrm{~h}$ & 31.9 & 4.7 & 8.9 & 14.7 & 1.7 & 38.1 \\
\hline
\end{tabular}


According to previous evidence, single NFs-layers—with and without keratin-have been tested by in vitro studies. Qualitative evaluation by SEM of hMSCs' adhesion and spreading after $24 \mathrm{~h}$ onto different KSPVA samples are shown in Figure 4a. Quantitative adhesion results were calculated assuming that the total cell attachment corresponds to the cell culture plate. The average percentage of attached cells in all KSPVA-NFs overcame the value of $60 \%$, better than PVA-NFs (Figure $4 \mathrm{~b}$ ). Cell adhesion after $24 \mathrm{~h}$ was around $90 \%$ in KSPVA1, independently of the temperature treatment. This result is ascribable to the presence of wool-keratin onto NFs (owing to the presence of integrin binding motifs [41]), as well as to the variations in WCA, PVA-crystallinity, and the secondary structure content of KS.

(a)
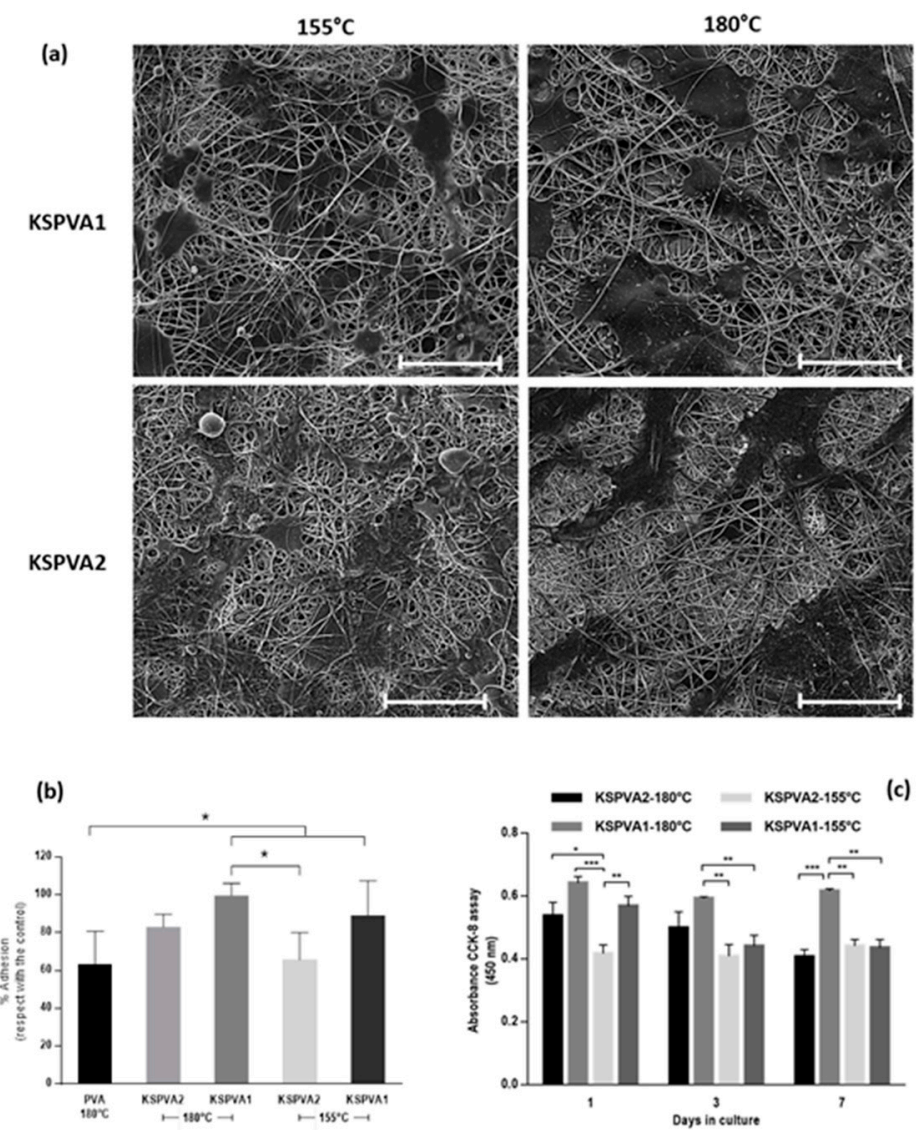

Figure 4. SEM images (scale bar $50 \mu \mathrm{m})(\mathbf{a})$ and quantitative results (b) of hMSCs' adhesion onto KSPVA fibers after $24 \mathrm{~h}$. (c) hMSCs' viability assay on KSPVA2 and KSPVA1 treated at different temperatures. $\left({ }^{*} p<0.05,{ }^{* *} p<0.01,{ }^{* * *} p<0.001\right)$.

The hMSCs' proliferation was measured by the absorbance of CCK-8 reagent, which is proportional to living cells (Figure 4c). Because the KSPVA1 sample at different temperature treatments showed better cell adhesion after $24 \mathrm{~h}$, the hMSCs' proliferation also reflected similar results. For the following days, cell proliferation values of KSPVA1 were almost constant for samples treated at $180^{\circ} \mathrm{C}$; meanwhile, the proliferation values of KSPVA1 treated at $155^{\circ} \mathrm{C}$ decreased after 3 days. These results could be related to better stability of fibers conferred by the temperature treatment without altering the morphology and protein chains, as reported previously [19]. Moreover, the secondary structure content of $\mathrm{KSPVA} 1-180^{\circ} \mathrm{C}$ allows preserving more efficiently the biological stability of wool-KS, as confirmed by the biological results. It is noteworthy that no increase in cell proliferation was recorded in any other case, independently of temperature treatment and composition. This could be because of the effect of keratin release that negatively influences surface and

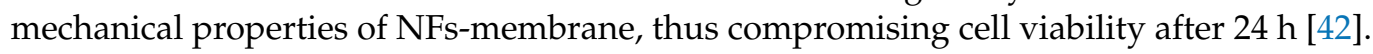




\section{Discussion}

Over time, the production of NFs by electrospinning has been recognized as an invaluable processing technique for the fabrication of substrates for skin substitution and wound healing [43]. Indeed, this technology joined the need to manufacture as nature by combining cells, ECM, and/or biomaterials to produce intricate living or non-living biological products. In the case of wound healing applications, it is well known that dressing materials play a crucial role during the repair processes in terms of surface protection, molecular transport, ion delivery, bacteriostatic function regulation, and cell interactions [44-46]. From this point of view, electrospun-NFs must not contain any traces of solvents post-fabrication-accordingly, the use of solvents such as TFE, DMF, or DCM is only restricted to pharmaceutical use by the U.S. Food and Drug Administration [47]. The polymer processing in aqueous solutions allows to minimize the manufacturing impact on the patient's health, also facilitating the clinical translation of electrospinning products into green materials [48].

By and large, scaffolds must have functional architectures with tunable chemical and structural properties, supporting wound healing processes and simultaneously inhibiting bacteria activities $[49,50]$. However, most substrates for wound healing are still based on single-layer NFs, which partially satisfy these requirements. Currently, several efforts have been spent to design innovative strategies to increase the chemical and structural complexity of electrospun dressing platforms that overcome the limits of traditional dressings (i.e., cotton knitted textiles) without any active function in the healing process [51]. Other strategies also proposed the integration of nanoparticles loaded with antibiotics (i.e., such as tetracyclines [52] or other actives macromolecules (e.g., proteins [53] or essential oils [54])) with antibacterial properties to treat local infections accurately.

This work proposes an alternative approach that involves the use of electrospun asymmetric platforms as a strategy to replicate anatomic skin features during the repair process, with relevant enhancements in wound healing [55]. Asymmetry membranes are twolayered structures capable of mimicking the properties of both skin layers-epidermis and dermis. On the top (epidermis side), the system is characterized by a layer of cross-linked PVA-NFs that assure a dense structure with sufficient wettability to play a protective role of the wound site, limiting rapid dehydration of the surface and minimizing the diffusion of microorganisms (i.e., bacteria). On the bottom (dermis side), the system presents an interconnected porous layer with high absorption capacity to regulate the fluid adsorption, molecular transport, and complete drainage of the wound site. Indeed, the swelling properties of PVA-NFs are improved by wool-keratin with its bioactive properties that assure a more efficient interface with cells and enhanced intrinsic antibacterial properties, as reported in several studies [56].

In comparison with other epithelial components (i.e., gelatin, elastin, collagen, and sericin), extracted-keratin is a biodegradable and water-soluble protein with a cytocompatibility and non-immunogenic response due to their peculiar cell-binding motifs (i.e., arginine-glycine-aspartic acid) [57,58]. Recent studies confirmed the advantages of using keratin electrospun-NFs for wound healing applications because of their high porosity and capacity to absorb exudates [59]. Different content of KS and thermal treatments enables modifying the wettability, the microscopic properties of NFs, and the secondary structure content of KS, which confer different properties in terms of flexibility and chain elasticity, able to slightly influence cell response in vitro, in agreement with previous studies [60]. Accordingly, KS-NFs have also been combined with other proteins such as gelatin to design bilayered platforms able to improve the in vitro interactions with L929 fibroblasts, also promoting in vivo earlier vascularization and better skin wound healing [61]. In our work, we have proposed to use PVA, thanks to relevant benefits in terms of chemical stability and transport properties that characterize ionotropic polymer-such as PVA-with respect to structural proteins-such as gelatin.

Indeed, PVA and KS are recognized biocompatible materials, able to influence the cellmaterial interaction mechanisms in terms of adhesion and spreading, as well as assuring 
an accurate modulation of mechanical properties [62]. On the one hand, the combination of KS and PVA can improve the in vitro stability of the upper layer and, on the other hand, ensure an optimal mass transport of small molecules through the bottom one, giving, in perspective, the opportunity to more efficiently exchange the molecular signal at the wound site and to support the release of antimicrobial (i.e., antibiotic) molecules to fight bacteria through controlled release strategies.

\section{Conclusions}

This work proposes the design of electrospun-NFs from aqueous solutions to assembly asymmetric membranes as a promising strategy to support skin regeneration and wound healing. The top layer is composed of PVA-NFs to replicate the chemical stability and wettability features of the epidermis. Morphological studies confirmed that PVA-NFs satisfy ideal requirements for the top layer in terms of diameter distribution and porosity. Secondly, the bottom layer is fabricated by integrating PVA with wool-keratin extracted via sulfitolysis. In vitro tests highlighted an evident improvement of cell adhesion due to the presence of keratin and its recognized biocompatibility and wettability, suitable to mimic the properties of the dermis. Furthermore, the KS content and thermal treatment of NFs were demonstrated to have a relevant effect on PVA-crystallinity, whose variations influence the secondary structure content of proteins at different levels (i.e., $\alpha$-helix and $\beta$-turns). The combination of PVA and high in vitro stability and bioactive proteins like keratin could be promising to design asymmetric membranes able to confine active species (i.e., antioxidants, antimicrobials) into the bottom layer and sustain, more specifically, cell activities (i.e., proliferation, differentiation) in the wound site.

Author Contributions: Conceptualization, V.G.; experimental analyses, D.O.S.R., I.C.-M. and C.T.; writing-original draft preparation, D.O.S.R., I.C.-M. and V.G.; writing-review and editing, V.G., C.V. and A.V.; supervision, C.V., A.V. and V.G. All authors have read and agreed to the published version of the manuscript.

Funding: This research received no external funding.

Institutional Review Board Statement: Not applicable.

Informed Consent Statement: Not applicable.

Data Availability Statement: Not applicable.

Conflicts of Interest: The authors declare no conflict of interest.

\section{References}

1. Borena, B.M.; Martens, A.; Broeckx, S.Y.; Meyer, E.; Chiers, K.; Duchateau, L.; Spaas, J.H. Regenerative Skin Wound Healing in Mammals: State-of-the-Art on Growth Factor and Stem Cell Based Treatments. Cell. Physiol. Biochem. 2015, 36, 1-23. [CrossRef] [PubMed]

2. Tottoli, E.M.; Dorati, R.; Genta, I.; Chiesa, E.; Pisani, S.; Conti, B. Skin Wound Healing Process and New Emerging Technologies for Skin Wound Care and Regeneration. Pharmaceutics 2020, 12, 735. [CrossRef] [PubMed]

3. Boyce, S.T.; Lalley, A.L. Tissue engineering of skin and regenerative medicine for wound care. Burn. Trauma 2018, 6, 4. [CrossRef] [PubMed]

4. Afsharian, Y.P.; Rahimnejad, M. Bioactive electrospun scaffolds for wound healing applications: A comprehensive review. Polym. Test. 2021, 93, 106952. [CrossRef]

5. Abdal-Hay, A.; Hussein, K.H.; Casettari, L.; Khalil, K.A.; Hamdy, A.S. Fabrication of novel high performance ductile poly(lactic acid) nanofiber scaffold coated with poly(vinyl alcohol) for tissue engineering applications. Mater. Sci. Eng. C 2016, 60, 143-150. [CrossRef]

6. You, Y.; Park, W.H.; Ko, B.M.; Min, B.-M. Effects of PVA sponge containing chitooligosaccharide in the early stage of wound healing. J. Mater. Sci. Mater. Electron. 2004, 15, 297-301. [CrossRef] [PubMed]

7. Huang, M.-H.; Yang, M.-C. Evaluation of glucan/poly(vinyl alcohol) blend wound dressing using rat models. Int. J. Pharm. 2008, 346, 38-46. [CrossRef]

8. Gupta, A.; Kumar, R.; Upadhyay, N.K.; Surekha, P.; Roy, P.K. Synthesis, characterization and efficacy of chemically crosslinked PVA hydrogels for dermal wound healing in experimental animals. J. Appl. Polym. Sci. 2009, 111, 1400-1408. [CrossRef] 
9. Kim, J.O.; Park, J.K.; Kim, J.H.; Jin, S.G.; Yong, C.S.; Li, D.X.; Choi, J.Y.; Woo, J.S.; Yoo, B.K.; Lyoo, W.S.; et al. Development of polyvinyl alcohol-sodium alginate gel-matrix-based wound dressing system containing nitrofurazone. Int. J. Pharm. 2008, 359, 79-86. [CrossRef]

10. Niranjan, R.; Kaushik, M.; Prakash, J.; Venkataprasanna, K.S.; Arpana, C.; Balashanmugam, P.; Venkatasubbu, G.D. Enhanced wound healing by PVA/Chitosan/Curcumin patches: In vitro and in vivo study. Colloids Surfaces B Biointerfaces 2019, 182, 110339. [CrossRef]

11. Bi, H.; Feng, T.; Li, B.; Han, Y. In Vitro and In Vivo Comparison Study of Electrospun PLA and PLA/PVA/SA Fiber Membranes for Wound Healing. Polymers 2020, 12, 839. [CrossRef]

12. Jatoi, A.W.; Ogasawara, H.; Kim, I.S.; Ni, Q.-Q. Polyvinyl alcohol nanofiber based three phase wound dressings for sustained wound healing applications. Mater. Lett. 2019, 241, 168-171. [CrossRef]

13. Khabbaz, B.; Solouk, A.; Mirzadeh, H. Polyvinyl alcohol/soy protein isolate nanofibrous patch for wound-healing applications. Prog. Biomater. 2019, 8, 185-196. [CrossRef] [PubMed]

14. Guarino, V.; Cirillo, V.; Ambrosio, L. Bicomponent electrospun scaffolds to design extracellular matrix tissue analogs. Expert Rev. Med. Devices 2015, 13, 83-102. [CrossRef] [PubMed]

15. Cruz-Maya, I.; Guarino, V.; Almaguer-Flores, A.; Alvarez-Perez, M.A.; Varesano, A.; Vineis, C. Highly polydisperse keratin rich nanofibers: Scaffold design and in vitro characterization. J. Biomed. Mater. Res. Part A 2019, 107, 1803-1813. [CrossRef] [PubMed]

16. Cruz-Maya, I.; Varesano, A.; Vineis, C.; Guarino, V. Comparative Study on Protein-Rich Electrospun Fibers for in Vitro Applications. Polymers 2020, 12, 1671. [CrossRef] [PubMed]

17. Varesano, A.; Vineis, C.; Tonetti, C.; Sanchez Ramirez, D.O.; Mazzuchetti, G. Chemical and physical modifications of electrospun keratin nanofibers induced by heating treatments. J. Appl. Polym. Sci. 2014, 131, 40532. [CrossRef]

18. Hong, K.H.; Park, J.L.; Sul, I.H.; Youk, J.H.; Kang, T.J. Preparation of antimicrobial poly(vinyl alcohol) nanofibers containing silver nanoparticles. J. Polym. Sci. Part B Polym. Phys. 2006, 44, 2468-2474. [CrossRef]

19. Varesano, A.; Vineis, C.; Tonetti, C.; Sanchez Ramirez, D.O.; Mazzuchetti, G.; Ortelli, S.; Blosi, M.; Costa, A. Multifunctional Hybrid Nanocomposite Nanofibers Produced by Colloid Electrospinning from Water Solutions. Curr. Nanosci. 2014, 11, 41-48. [CrossRef]

20. van de Weert, M.; Haris, P.I.; Hennink, W.E.; Crommelin, D.J. Fourier Transform Infrared Spectrometric Analysis of Protein Conformation: Effect of Sampling Method and Stress Factors. Anal. Biochem. 2001, 297, 160-169. [CrossRef]

21. Cobb, J.S.; Zai-Rose, V.; Correia, J.J.; Janorkar, A.V. FT-IR Spectroscopic Analysis of the Secondary Structures Present during the Desiccation Induced Aggregation of Elastin-Like Polypeptide on Silica. ACS Omega 2020, 5, 8403-8413. [CrossRef] [PubMed]

22. Troullier, A.; Reinstädler, D.; Dupont, Y.; Naumann, D.; Forge, V. Transient non-native secondary structures during the refolding of alpha-lactalbumin detected by infrared spectroscopy. Nat. Genet. 2000, 7, 78-86. [CrossRef]

23. Baird, G.; Farrell, C.; Cheung, J.; Semple, A.; Blue, J.; Ahl, P.L. FTIR Spectroscopy Detects Intermolecular $\beta$-Sheet Formation Above the High Temperature Tm for Two Monoclonal Antibodies. Protein J. 2020, 39, 318-327. [CrossRef] [PubMed]

24. Tian, F.; Middaugh, C.R.; Offerdahl, T.; Munson, E.; Sane, S.; Rytting, J.H. Spectroscopic evaluation of the stabilization of humanized monoclonal antibodies in amino acid formulations. Int. J. Pharm. 2007, 335, 20-31. [CrossRef] [PubMed]

25. Belton, D.J.; Plowright, R.; Kaplan, D.L.; Perry, C.C. A robust spectroscopic method for the determination of protein conformational composition-Application to the annealing of silk. Acta Biomater. 2018, 73, 355-364. [CrossRef]

26. DeFlores, L.P.; Ganim, Z.; Nicodemus, R.A.; Tokmakoff, A. Amide I'-II' 2D IR Spectroscopy Provides Enhanced Protein Secondary Structural Sensitivity. J. Am. Chem. Soc. 2009, 131, 3385-3391. [CrossRef] [PubMed]

27. Cardamone, J.M. Investigating the microstructure of keratin extracted from wool: Peptide sequence (MALDI-TOF/TOF) and protein conformation (FTIR). J. Mol. Struct. 2010, 969, 97-105. [CrossRef]

28. Litvinov, R.; Faizullin, D.A.; Zuev, Y.; Weisel, J.W. The $\alpha$-Helix to $\beta$-Sheet Transition in Stretched and Compressed Hydrated Fibrin Clots. Biophys. J. 2012, 103, 1020-1027. [CrossRef]

29. Secundo, A.F.; Guerrieri, N. ATR-FT/IR Study on the Interactions between Gliadins and Dextrin and Their Effects on Protein Secondary Structure. J. Agric. Food Chem. 2005, 53, 1757-1764. [CrossRef]

30. Holland, B.; Hay, J. The thermal degradation of poly(vinyl alcohol). Polymer 2001, 42, 6775-6783. [CrossRef]

31. Kim, S.J.; Park, S.J.; Kim, I.Y.; Lee, Y.H.; Kim, S.I. Thermal characteristics of poly(vinyl alcohol) and poly(vinylpyrrolidone) IPNs. J. Appl. Polym. Sci. 2002, 86, 1844-1847. [CrossRef]

32. Xue, B.; Zhang, J.; Zhou, T. Moving-window two-dimensional correlation infrared spectroscopic study on the dissolution process of poly(vinyl alcohol). Anal. Bioanal. Chem. 2015, 407, 8765-8771. [CrossRef]

33. Cardamone, J.M. Keratin transamidation. Int. J. Biol. Macromol. 2008, 42, 413-419. [CrossRef]

34. Jackson, M.; Mantsch, H.H. The Use and Misuse of FTIR Spectroscopy in the Determination of Protein Structure. Crit. Rev. Biochem. Mol. Biol. 1995, 30, 95-120. [CrossRef] [PubMed]

35. Erra, P.; Gómez, N.; Dolcet, L.M.; Juliá, M.R.; Lewis, D.M.; Willoughby, J.H. FTIR Analysis to Study Chemical Changes in Wool Following a Sulfitolysis Treatment. Text. Res. J. 1997, 67, 397-401. [CrossRef]

36. Mansur, H.; Sadahira, C.M.; Souza, A.N.; Mansur, A. FTIR spectroscopy characterization of poly (vinyl alcohol) hydrogel with different hydrolysis degree and chemically crosslinked with glutaraldehyde. Mater. Sci. Eng. C 2008, 28, 539-548. [CrossRef]

37. Raksa, A.; Utke, R.; Ruksakulpiwat, C.; Numpaisal, P.-O.; Ruksakulpiwat, Y. Morphological and chemical characterization of electrospun silk fibroin/polyvinyl alcohol nanofibers. Second. Mater. Res. Soc. Thail. Int. Conf. 2020, 2279, 080004. [CrossRef] 
38. Park, C.; Carlson, M.J.; Goddard, W.A. Solvent Effects on the Secondary Structures of Proteins. J. Phys. Chem. A 2000, 104, 2498-2503. [CrossRef]

39. Christensen, L.F.B.; Nowak, J.S.; Sønderby, T.V.; Frank, S.A.; Otzen, D.E. Quantitating denaturation by formic acid: Imperfect repeats are essential to the stability of the functional amyloid protein FapC. J. Biol. Chem. 2020, 295, 13031-13046. [CrossRef]

40. Colomer, I.; Batchelor-McAuley, C.; Odell, B.; Donohoe, T.J.; Compton, R.G. Hydrogen Bonding to Hexafluoroisopropanol Controls the Oxidative Strength of Hypervalent Iodine Reagents. J. Am. Chem. Soc. 2016, 138, 8855-8861. [CrossRef]

41. Arima, Y.; Iwata, H. Effect of wettability and surface functional groups on protein adsorption and cell adhesion using well-defined mixed self-assembled monolayers. Biomaterials 2007, 28, 3074-3082. [CrossRef]

42. Guo, T.; Yang, X.; Deng, J.; Zhu, L.; Wang, B.; Hao, S. Keratin nanoparticles-coating electrospun PVA nanofibers for potential neural tissue applications. J. Mater. Sci. Mater. Med. 2019, 30, 1-9. [CrossRef] [PubMed]

43. Gao, X.; Han, S.; Zhang, R.; Liu, G.; Wu, J. Progress in electrospun composite nanofibers: Composition, performance and applications for tissue engineering. J. Mater. Chem. B 2019, 7, 7075-7089. [CrossRef] [PubMed]

44. Pires, L.R.; Guarino, V.; Oliveira, M.J.; Ribeiro, C.C.; A Barbosa, M.; Ambrosio, L.; Pêgo, A.P. Ibuprofen-loaded poly(trimethylene carbonate-co- $\varepsilon$-caprolactone) electrospun fibres for nerve regeneration. J. Tissue Eng. Regen. Med. 2016, 10, E154-E166. [CrossRef] [PubMed]

45. Chong, E.J.; Phan, T.T.; Lim, I.J.; Zhang, Y.; Bay, B.H.; Ramakrishna, S.; Lim, C.T. Evaluation of electrospun PCL/gelatin nanofibrous scaffold for wound healing and layered dermal reconstitution. Acta Biomater. 2007, 3, 321-330. [CrossRef] [PubMed]

46. Babaeijandaghi, F.; Shabani, I.; Seyedjafari, E.; Naraghi, Z.S.; Vasei, M.; Haddadi-Asl, V.; Hesari, K.K.; Soleimani, M. Accelerated Epidermal Regeneration and Improved Dermal Reconstruction Achieved by Polyethersulfone Nanofibers. Tissue Eng. Part A 2010, 16, 3527-3536. [CrossRef] [PubMed]

47. International Council for Harmonisation 2018 Impurities: Guideline for residual solvents Q3C (R7). Curr. Step 2005, 4, 509.

48. Mosher, C.Z.; Brudnicki, P.A.P.; Gong, Z.; Childs, H.R.; Lee, S.W.; Antrobus, R.M.; Fang, E.C.; Schiros, T.N.; Lu, H.H. Green electrospinning for biomaterials and biofabrication. Biofabrication 2021, 13, 035049. [CrossRef]

49. Negut, I.; Grumezescu, V.; Grumezescu, A.M. Treatment Strategies for Infected Wounds. Molecules 2018, 23, 2392. [CrossRef]

50. Liu, G.; Bao, Z.; Wu, J. Injectable baicalin/F127 hydrogel with antioxidant activity for enhanced wound healing. Chin. Chem. Lett. 2020, 31, 1817-1821. [CrossRef]

51. Pilehvar-Soltanahmadi, Y.; Dadashpour, M.; Mohajeri, A.; Fattahi, A.; Sheervalilou, R.; Zarghami, N. An Overview on Application of Natural Substances Incorporated with Electrospun Nanofibrous Scaffolds to Development of Innovative Wound Dressings. Mini-Rev. Med. Chem. 2018, 18, 414-427. [CrossRef] [PubMed]

52. Khodir, W.W.A.; Guarino, V.; Alvarez-Perez, M.; Cafiero, C.; Ambrosio, L. Trapping tetracycline-loaded nanoparticles into polycaprolactone fiber networks for periodontal regeneration therapy. J. Bioact. Compat. Polym. 2013, 28, 258-273. [CrossRef]

53. Khodir, W.K.W.A.; Razak, A.H.A.; Ng, M.H.; Guarino, V.; Susanti, D. Encapsulation and Characterization of Gentamicin Sulfate in the Collagen Added Electrospun Nanofibers for Skin Regeneration. J. Funct. Biomater. 2018, 9, 36. [CrossRef] [PubMed]

54. García-Salinas, S.; Evangelopoulos, M.; Gámez-Herrera, E.; Arruebo, M.; Irusta, S.; Taraballi, F.; Mendoza, G.; Tasciotti, E. Electrospun anti-inflammatory patch loaded with essential oils for wound healing. Int. J. Pharm. 2020, 577, 119067. [CrossRef] [PubMed]

55. Miguel, S.A.P.; Simões, D.; Moreira, A.F.; Sequeira, R.S.; Correia, I.J. Production and characterization of electrospun silk fibroin based asymmetric membranes for wound dressing applications. Int. J. Biol. Macromol. 2019, 121, 524-535. [CrossRef]

56. Akhmetova, A.; Heinz, A. Electrospinning Proteins for Wound Healing Purposes: Opportunities and Challenges. Pharmaceutics 2020, 13, 4. [CrossRef]

57. Vineis, C.; Maya, I.C.; Mowafi, S.; Varesano, A.; Sanchez Ramirez, D.O.; Taleb, M.A.; Tonetti, C.; Guarino, V.; El-Sayed, H. Synergistic effect of sericin and keratin in gelatin based nanofibers for in vitro applications. Int. J. Biol. Macromol. 2021, 190, 375-381. [CrossRef] [PubMed]

58. Ferraris, S.; Guarino, V.; Cochis, A.; Varesano, A.; Maya, I.C.; Vineis, C.; Rimondini, L.; Spriano, S. Aligned keratin submicrometricfibers for fibroblasts guidance onto nanogrooved titanium surfaces for transmucosal implants. Mater. Lett. 2018, $229,1-4$. [CrossRef]

59. Hamdan, N.; Yamin, A.; Hamid, S.A.; Khodir, W.K.W.A.; Guarino, V. Functionalized Antimicrobial Nanofibers: Design Criteria and Recent Advances. J. Funct. Biomater. 2021, 12, 59. [CrossRef]

60. Chen, B.; Xing, Y.; Yu, W.; Liu, H. Wool keratin and silk sericin composite films reinforced by molecular network reconstruction. J. Mater. Sci. 2017, 53, 5418-5428. [CrossRef]

61. Yao, C.-H.; Lee, C.-Y.; Huang, C.-H.; Chen, Y.-S.; Chen, K.-Y. Novel bilayer wound dressing based on electrospun gelatin/keratin nanofibrous mats for skin wound repair. Mater. Sci. Eng. C 2017, 79, 533-540. [CrossRef] [PubMed]

62. Ranjbar-Mohammadi, M.; Arab-Bafrani, Z.; Karimi, F.; Javid, N. Designing hybrid nanofibers based on keratin-poly (vinyl alcohol) and poly ( $\epsilon$-caprolactone) for application as wound dressing. J. Ind. Text. 2021, 1528083721988978. [CrossRef] 